\title{
Evaluation of Occupational and Professional Profiles in Ecuadorian Context Based on Guide of Knowledge Swebok and Ontological Model
}

\author{
Pablo Alejandro Quezada-Sarmiento, Mary Morocho- \\ Quezada and Liliana Pacheco-Jara
}

\author{
Juan Garbajosa
}

\begin{abstract}
Bodies of Knowledge (BOK), contain the relevant knowledge for a discipline, and it is necessary for the development of the science, and application in the professional, and occupational profiles, and the possible incidence in the industry of Ecuador. In this paper, it is shown an evaluation of professional and occupational profiles based on standard Software Engineering Body of Knowledge SWEBOK 2004 (Spanish Version), and the development of ontological model, in order to obtain the necessary information to establish the relationship, and the criteria to evaluate the profiles based on the guide of knowledge.
\end{abstract}

Keywords-Bodies of Knowledge; BOK; Evaluation; Guide; Ecuador; Model; Ontologies; Professional; Standard.

\section{INTRODUCTION}

The emergence of the competencies approach worldwide, it is related to productive changes because of the ongoing global change; Ecuadorian industries have understood the need to prevail in the market creating competitive advantages. The human factor is one of the strongest strategic components, the contribution made people is linked fully with the strategies of competitiveness required to be part of an organization, forcing employers to make a careful selection of profiles professionals, depending on the occupational profiles requiring [16]

In Ecuador, the "Secretaría Técnica de Capacitación y Formación Profesional (SETEC)", execute some aggregators value processes. One of this process is the "Orientation of Competences and Certification", that "establish the methodological guidelines for the identification, uprising, and validation of occupational profiles, and a competence standards", the same work as the basis for the development of training and certification processes for occupational profiles [17].

BOK contains the relevant knowledge for a discipline. BOK must be embodying the consensus reached by the community; for this reason BOK will be of applicate. This consensus is a prerequisite for the adoption of the BOK by the community [9]. BOK may include technical terms and theoretical concepts as well as recommended practices [14]. $\mathrm{BOK}$ is a common intellectual ground. It is shared by everyone in the profession regardless of employment or engineering discipline; for this reason; in this paper shown the evaluation of occupational and professional profiles, based in the guide SWEBOK 2004 (Spanish Version), which is a popular guide in the field of Software Engineering (SE).

In order to evaluate occupational, and professional profiles, it was used the guide SWEBOK 2004 (Spanish Version) [3], and characterization of ontological model supported by Neon Methodology [10]. The purpose of this research, it was to establish a model to evaluate occupational and professional profiles taking as points of mediation de guide SWEBOK 2004 (Spanish Version) [3].

This paper has been structured as follows: Section I, contains the Introduction, section II introduces Related Works, section III describes the Research Methodology used; then Section IV introduces some conclusions, Section V contains the Acknowledgment, and the last section contains the references that support this research.

\section{RELATED WORKS}

The use of BOK has increased representatively; according to [2], and [13], the use for developing ontological models for BOK based in knowledge, and applied in the monitoring of networks around a community are explain; however in [5], used BOK for the conceptualization of shared knowledge between humans, and software. They also mention that the use of BOK in building ontologies for information systems and management development software. Moreover, BOK meets the set of skills, knowledge, and attitudes required for professional domain [1].

$\mathrm{BOK}$ is used as points of comparison mediation of powers between work, and academic contexts. For example in [8], a model using DISCO II is proposed for the creation, and comparison of profiles based on competencies. In [7], proposed a model for competence, and its components that is used as a point of mediation for the comparison of academic and occupational profiles. In [1], a useful model is proposed not only in academia but also in industry, where SWEBOK 2004 specifies the Knowledge Areas (KA) necessaries in this 
context. In [2], extend the research [1], associating skill levels of Bloom's taxonomy of knowledge area, and SWEBOK profiles Guide Software Engineering: New Graduate, Graduate with four years of experience, and experienced software engineer working in a software engineering process group.

\section{METHODOLOGY}

In order to development the evaluation of occupational, and professional profiles in Ecuadorian context, based in guide SWEBOK 2004, (Spanish version), and ontological model it was necessary use $\mathrm{NeOn}$ scenarios.

\section{A. Step 1: Define ontological model.}

In recent years, it has increased the interest of professionals in the development, and management of ontologies to develop from scratch, with the aim of linking knowledge and providing a semantic sense. Some of the most widely used methods are as follows: METHONTOLOGY [18], On-To-Knowledge [19], and DILIGENT [20]. One of the methodologies used to for that development the ontological model is called NeOn. NeOn is based on nine stages, since there are several ways for building ontologies. $\mathrm{NeOn}$ scenarios are flexible, allowing combined scenarios, and allowing users to customize them. For the evaluation of the profiles, the following methodology of NeOn scenarios is used:

1) Scenario 1: From specification to implementation.

a) PURPOSE: To develop ontology based on BOK; it will serve as a vocabulary to describe the terms associated with that domain of application.

b) SCOPE: The ontology was focused on domain of $\mathrm{BOK}$, it will be of general use to those interested in this field; with which greater knowledge will enhance on how they are structured BOK in the various disciplines such activity is related.

The proposal of this research is to study the structure of SWEBOK 2004 (Spanish Version) in order to evaluate the professional, and occupational profiles in Ecuadorian context.

c) EXPECTED END USERS: When a new ontology is designed, it is important to evaluate possible users. In table I, it is showed some examples of stakeholders.

TABLE I. EXPECTED END USERS

\begin{tabular}{|c|l|}
\hline \multicolumn{2}{|c|}{ EXPECTED END USERS } \\
\hline Engineers & People who study engineering [3]. \\
\hline Graduates & $\begin{array}{l}\text { Person who acquire an academic degree after } \\
\text { complete the studies [1]. }\end{array}$ \\
\hline Stakeholders & $\begin{array}{l}\text { Many people, groups, companies, and other } \\
\text { organizational or governmental entities have a stake in } \\
\text { educational programs [9]. }\end{array}$ \\
\hline
\end{tabular}

\section{d) REQUIREMENTS}

a. Functional Requirements:

i. How is knowledge described? ii. How to evaluate Occupational and Professional profiles using SWEBOK 2004 (Spanish version)?

b. Non-functional Requirements

i. The ontology will be developed in English.

2) Scenario 2: Reusing and re-engineering nonontological resources (NORs).

The reuse of Non-ontological resources is the second activity of $\mathrm{NeOn}$ which is the same methodology for analyzing non-ontological resources. In table II, the non-ontological resources necessary for the evaluation of profiles are described.

\section{TABLE II. NO-ONTOLOGYCAL RESOURCES}

\begin{tabular}{|c|c|c|}
\hline \multicolumn{3}{|c|}{ NO-ONTOLOGICCAL RESOURSES } \\
\hline Class & Class Description & Properties \\
\hline $\begin{array}{l}\text { BOK Ontological } \\
\text { Model with } \\
\text { Standars }\end{array}$ & Name of Ontological Model & include \\
\hline $\begin{array}{l}\text { Body of } \\
\text { Knowledge }\end{array}$ & $\begin{array}{l}\text { Contain the relevant } \\
\text { Knowledge for a discipline. BOK must } \\
\text { embody the consensus reached by the } \\
\text { community for which this BOK will be of } \\
\text { application. This consensus is a } \\
\text { prerequisite for the adoption of the BOK } \\
\text { by the community [9]. }\end{array}$ & $\begin{array}{c}\text { id } \\
\text { code } \\
\text { levelsOfAbstraction } \\
\text { context } \\
\text { streture_by }\end{array}$ \\
\hline Knowledge Area & $\begin{array}{l}\text { tructure of a body of knowledge which } \\
\text { define what a professional needs to } \\
\text { understand and the tasks a practitioner } \\
\text { must be able to perform. [2]. }\end{array}$ & $\begin{array}{l}\text { require } \\
\text { composed by }\end{array}$ \\
\hline Unit & $\begin{array}{l}\text { Each area is broken down into smaller } \\
\text { divisions. [2]. }\end{array}$ & $\begin{array}{l}\text { id } \\
\text { code } \\
\text { description } \\
\text { involve }\end{array}$ \\
\hline Topics & Second level of knowledge structure. [2]. & $\begin{array}{c}\text { associate } \\
\text { columnMatrix } \\
\text { matriXTopicAndReference } \\
\text { id } \\
\text { code } \\
\text { description }\end{array}$ \\
\hline Subtopic & Description of each Topic [2]. & $\begin{array}{c}\text { id } \\
\text { code } \\
\text { description }\end{array}$ \\
\hline Profiles & $\begin{array}{l}\text { A set of characteristics that identify or are } \\
\text { thought to identify a particular type of } \\
\text { knowledge. [2]. }\end{array}$ & $\begin{array}{l}\text { need } \\
\text { is part of } \\
\text { id } \\
\text { description } \\
\text { code } \\
\text { typeProfile }\end{array}$ \\
\hline Skills & $\begin{array}{l}\text { An ability and capacity acquired through } \\
\text { deliberate, systematic, and sustained } \\
\text { effort to smoothly and adaptively carryout } \\
\text { complex activities or job functions } \\
\text { involving ideas (cognitive skills), things } \\
\text { (technical skills), and/or people } \\
\text { (interpersonal skills). [1] }\end{array}$ & $\begin{array}{c}\text { id } \\
\text { code } \\
\text { description }\end{array}$ \\
\hline detail_Profiles & $\begin{array}{l}\text { Specific characteristics of each profile } \\
{[2] .}\end{array}$ & $\begin{array}{c}\text { id } \\
\text { code } \\
\text { description }\end{array}$ \\
\hline
\end{tabular}




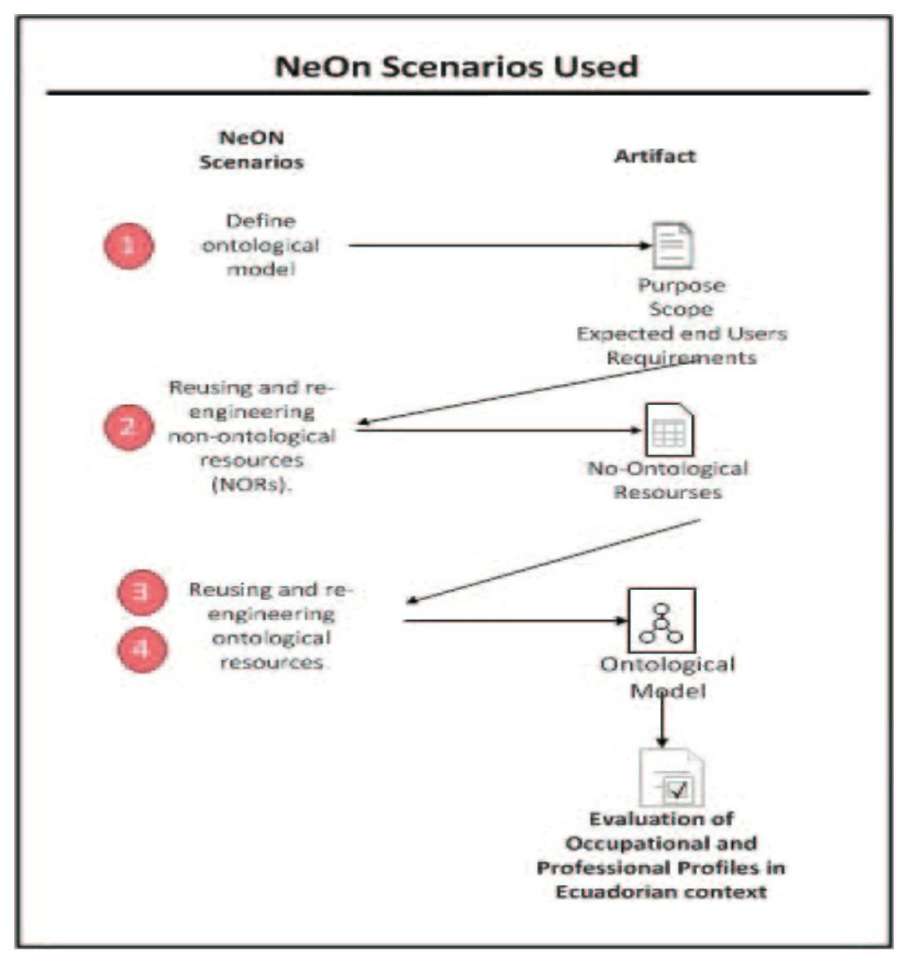

Fig. 1. NeON Scenarios

3) Scenario 3-4: Reusing and re-engineering ontological resources.

For the definition of the ontological model of BOK, the basis was it SWEBOK 2004 (Spanish version) are the same that are structured by KAS, which have several elements such as: knowledge Unit (KU), including a hierarchy of knowledge Topic (KT), and within knowledge subtopics (KST): List of further reading, References, taxonomies, List of acronyms, and labor profiles, and professionals requiring skills to define the knowledge professional levels [3].

The following ontological model has been developed using the scenarios of $\mathrm{NeOn}$ methodology, which were taking for building scenarios 1 to 4 that is showed in the figure 1 .

In the figure 2, the model is supported by the structure of the SWEBOK, with which it was possible to define the terminology of a domain of knowledge: the concepts that constitute the domain, and relationships between concepts. [15].

\section{B. Step 2: Evaluation of profiles through ontological models.}

The ontology proposal it was used to evaluate the occupational and professional profiles in the area of software engineering. General ontology concepts, and properties described in Scenario 2 were development, as these are needed for evaluation.

To evaluate profiles it was used SWEBOK 2004 (Spanish version), where only the Quality KA was used. The area is divided into $\mathrm{KU}$, and $\mathrm{KT}$, in order to deepen the concepts of knowledge and identify the sub-topics.

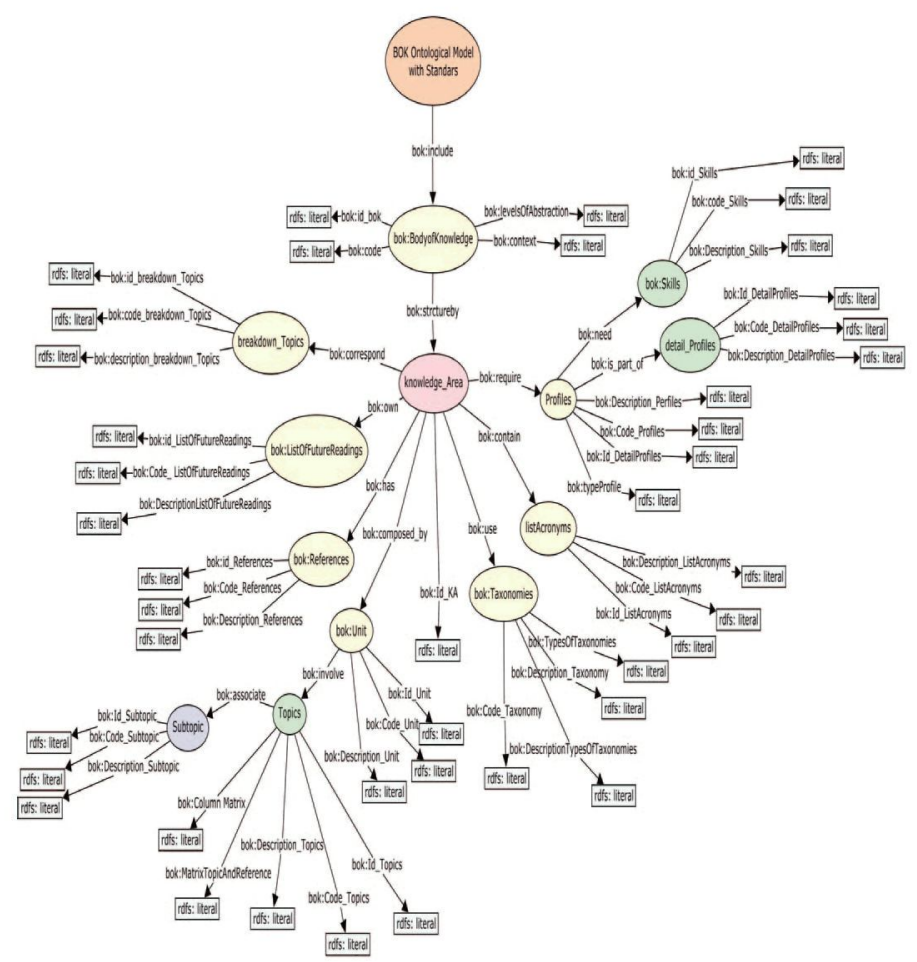

Fig. 2. Ontological Model to Describe BOK.

In a same way, it is necessary to consider another level in the structure of BOK, where the topics will be more detailed knowledge subtopics. These knowledge subtopics have addressed different knowledge, and skills. In the same way, to develop a BOK it is necessary to take into account: Process Model, Deliverables, Organization, Technology focus, Tools, Assignment focus, and Exercise domain [6].

The KST were extracted by experts of SE, each KST considered the breakdown of KT. Table III, shows the breakdown of the subtopics found in the KT of quality area.

TABLE III. BOK COMPONENTS SWEBOK 2004 (SPANISH VERSION) [3].

\begin{tabular}{|c|c|c|c|}
\hline \multicolumn{4}{|c|}{$\begin{array}{l}\text { DESGLOSE SWEBOK (AREA DE CONOCIMIENTO - CALIDAD } \\
\text { DEL SOFTWARE) }\end{array}$} \\
\hline $\begin{array}{l}\text { Area } \\
\text { de } \\
\text { Conoci } \\
\text { miento }\end{array}$ & Unidades & Tópicos & Subtopics \\
\hline \multirow{11}{*}{$\begin{array}{l}\text { Calidad } \\
\text { del } \\
\text { Software }\end{array}$} & \multirow{11}{*}{$\begin{array}{l}\text { Fundamentos } \\
\text { de Calidad de } \\
\text { Software }\end{array}$} & \multirow{5}{*}{$\begin{array}{c}\text { Ingeniería } \\
\text { del Software } \\
\text { Cultura y } \\
\text { Ética. }\end{array}$} & $\begin{array}{l}\text { Caracteristicas y Conceptos de } \\
\text { calidad de software }\end{array}$ \\
\hline & & & Desarrollo de software \\
\hline & & & Mantenimiento de Software \\
\hline & & & Requisitos de Software \\
\hline & & & $\begin{array}{l}\text { Métodos de medición y } \\
\text { criterios de aceptación para } \\
\text { evaluar la calidad }\end{array}$ \\
\hline & & \multirow{6}{*}{$\begin{array}{l}\text { Valor y } \\
\text { coste de la } \\
\text { calidad }\end{array}$} & Producto de Software \\
\hline & & & Exigencias de producto \\
\hline & & & Coste de prevención \\
\hline & & & Coste de apreciación \\
\hline & & & Coste de fracaso interno \\
\hline & & & Coste de fracaso externo \\
\hline
\end{tabular}




\begin{tabular}{|c|c|c|}
\hline & & Proyectos de software \\
\hline & & $\begin{array}{l}\text { Alcance del proyecto de } \\
\text { software }\end{array}$ \\
\hline & & Requisitos de Software \\
\hline & & Ciclo de vida de software \\
\hline & \multirow{11}{*}{$\begin{array}{l}\text { Modelos y } \\
\text { Característic } \\
\text { as de } \\
\text { Calidad }\end{array}$} & Calidad de software \\
\hline & & $\begin{array}{l}\text { Taxonomía o modelo de } \\
\text { calidad de software }\end{array}$ \\
\hline & & $\begin{array}{l}\text { Atributos de calidad de } \\
\text { software }\end{array}$ \\
\hline & & $\begin{array}{l}\text { Modelos de características de } \\
\text { calidad de software }\end{array}$ \\
\hline & & $\begin{array}{l}\text { Negociación de la calidad del } \\
\text { producto de software }\end{array}$ \\
\hline & & $\begin{array}{l}\text { Planificación de la calidad del } \\
\text { producto de software }\end{array}$ \\
\hline & & $\begin{array}{l}\text { Transación de la calidad del } \\
\text { producto de software }\end{array}$ \\
\hline & & Producto de Software \\
\hline & & $\begin{array}{l}\text { Modelos de Calidad del } \\
\text { producto de Software (Calidad } \\
\text { interna, externa y de empleo) }\end{array}$ \\
\hline & & $\begin{array}{l}\text { La calidad del proceso en la } \\
\text { ingeniería del software }\end{array}$ \\
\hline & & Calidad de producto software \\
\hline & \multirow{9}{*}{$\begin{array}{l}\text { Mejora de } \\
\text { calidad }\end{array}$} & Producto de Software \\
\hline & & $\begin{array}{l}\text { Procesos de ciclo de vida de } \\
\text { software }\end{array}$ \\
\hline & & $\begin{array}{l}\text { Proceso de detección de } \\
\text { error/defecto }\end{array}$ \\
\hline & & Proceso de mejora de calidad \\
\hline & & $\begin{array}{l}\text { Construcción en calidad, } \\
\text { mediante la prevención y } \\
\text { detección temprana de errores }\end{array}$ \\
\hline & & $\begin{array}{l}\text { Proceso de Ingeniería de } \\
\text { Software }\end{array}$ \\
\hline & & Evaluación del producto \\
\hline & & $\begin{array}{l}\text { Alcance del proyecto de } \\
\text { software }\end{array}$ \\
\hline & & Gerencia de proyectos \\
\hline \multirow{18}{*}{$\begin{array}{l}\text { Consideracion } \\
\text { es Prácticas }\end{array}$} & \multirow{12}{*}{$\begin{array}{l}\text { Aseguramie } \\
\text { nto de la } \\
\text { Calidad del } \\
\text { Software }\end{array}$} & Producto de Software \\
\hline & & $\begin{array}{l}\text { Procesos de ciclo de vida de } \\
\text { software }\end{array}$ \\
\hline & & Requisitos de Software \\
\hline & & $\begin{array}{l}\text { Planificación de la calidad del } \\
\text { producto de software }\end{array}$ \\
\hline & & Desarrollo de software \\
\hline & & Plan de calidad \\
\hline & & Mantenimiento de Software \\
\hline & & $\begin{array}{l}\text { Planes de gestión, desarrollo, y } \\
\text { mantenimiento para el software }\end{array}$ \\
\hline & & Estándares de calidad \\
\hline & & $\begin{array}{l}\text { Actividades y tareas } \\
\text { específicas de calidad }\end{array}$ \\
\hline & & $\begin{array}{l}\text { Gestión de configuración de } \\
\text { software }\end{array}$ \\
\hline & & Proyectos de software \\
\hline & & $\begin{array}{l}\text { Planificación de la verificación } \\
\text { y validación del producto }\end{array}$ \\
\hline & & $\begin{array}{l}\text { Procesos del ciclo de vida del } \\
\text { software }\end{array}$ \\
\hline & Verificacion & Desarrollo de software \\
\hline & Validación & Mantenimiento de Software \\
\hline & & $\begin{array}{l}\text { Verificación y validación del } \\
\text { producto }\end{array}$ \\
\hline & & $\begin{array}{l}\text { Técnicas y herramientas para } \\
\text { la verificación y validación del }\end{array}$ \\
\hline
\end{tabular}

\begin{tabular}{|c|c|c|}
\hline & & producto \\
\hline & \multirow{5}{*}{$\begin{array}{l}\text { Revisiones y } \\
\text { Auditorías }\end{array}$} & Revisiones de gestión \\
\hline & & Revisiones técnicas \\
\hline & & Inspecciones \\
\hline & & Walk-throughs \\
\hline & & Auditorias \\
\hline \multirow{36}{*}{$\begin{array}{l}\text { Procesos de } \\
\text { Gestión de } \\
\text { Calidad del } \\
\text { Software }\end{array}$} & \multirow{10}{*}{$\begin{array}{l}\text { Requerimien } \\
\text { tos de } \\
\text { calidad del } \\
\text { software }\end{array}$} & Factores de influencia \\
\hline & & Confiabilidad \\
\hline & & $\begin{array}{l}\text { Niveles de integridad del } \\
\text { software }\end{array}$ \\
\hline & & $\begin{array}{l}\text { Proceso de la calidad del } \\
\text { software }\end{array}$ \\
\hline & & Métodos de diseño \\
\hline & & Lenguajes de Programación \\
\hline & & Tecnologías de software \\
\hline & & Desarrollo de software \\
\hline & & Mantenimiento de Software \\
\hline & & $\begin{array}{l}\text { Taxonomía o modelo de } \\
\text { calidad de software }\end{array}$ \\
\hline & & $\begin{array}{l}\text { Modelos de fiabilidad } \\
\text { construidos en base a fallos } \\
\text { recogidos }\end{array}$ \\
\hline & Caracterizaci & Pruebas de software \\
\hline & $\begin{array}{c}\text { ón de } \\
\text { defectos }\end{array}$ & $\begin{array}{l}\text { Proceso de Ingeniería de } \\
\text { Software }\end{array}$ \\
\hline & & $\begin{array}{l}\text { Implementación de técnicas de } \\
\text { gestión de la calidad del } \\
\text { software }\end{array}$ \\
\hline & & Técnicas Estáticas \\
\hline & $\begin{array}{l}\text { Técnicas de } \\
\text { Gestión de }\end{array}$ & $\begin{array}{l}\text { Técnicas Intensivas de } \\
\text { personal }\end{array}$ \\
\hline & Calidad del & Técnicas Analíticas \\
\hline & Software & Técnicas Dinámicas \\
\hline & & Pruebas de calidad \\
\hline & & $\begin{array}{l}\text { Modelos de calidad del } \\
\text { software }\end{array}$ \\
\hline & & $\begin{array}{l}\text { Métricas de la calidad del } \\
\text { software }\end{array}$ \\
\hline & & Producto de Software \\
\hline & & Calidad de software \\
\hline & & $\begin{array}{l}\text { Procesos de ciclo de vida de } \\
\text { software }\end{array}$ \\
\hline & & $\begin{array}{l}\text { Procesos de calidad y mejora } \\
\text { del software }\end{array}$ \\
\hline & & $\begin{array}{l}\text { Coste de los procesos de } \\
\text { calidad }\end{array}$ \\
\hline & & $\begin{array}{l}\text { Modelos genéricos de coste de } \\
\text { calidad }\end{array}$ \\
\hline & Técnicas & Procesos de desarrollo \\
\hline & Dinámicas & $\begin{array}{l}\text { Proceso de Ingeniería de } \\
\text { Software }\end{array}$ \\
\hline & & $\begin{array}{l}\text { Gestión en Ingeniería del } \\
\text { Software }\end{array}$ \\
\hline & & $\begin{array}{l}\text { Informes de la gestión de } \\
\text { calidad de software }\end{array}$ \\
\hline & & $\begin{array}{l}\text { Métricas de calidad de } \\
\text { software }\end{array}$ \\
\hline & & $\begin{array}{l}\text { Procesos del ciclo de vida del } \\
\text { software }\end{array}$ \\
\hline & & $\begin{array}{l}\text { Proceso de Ingeniería de } \\
\text { Software }\end{array}$ \\
\hline & & $\begin{array}{l}\text { Gestión en Ingeniería del } \\
\text { Software }\end{array}$ \\
\hline & & $\begin{array}{l}\text { Procesos de desarrollo y } \\
\text { mantenimiento }\end{array}$ \\
\hline
\end{tabular}




\section{Step 3: Selection of occupational and professional profiles}

Given a corpus of both occupational and professional profiles, it was obtained from of universities and employment platforms of Ecuador, two samples were taken for evaluation with SWEBOK profiles, considering among them the naked eye that may have greater alignment with a possible minor alignment with the samples to be worked are:

\section{1) Possibly aligned \\ a) Engineering in Computer Systems and Computer. \\ b) Computer Engineering and Computer Science.}

\section{2) Not aligned}

a) Career Computer Education.

b) Electronic and Computer Engineering.

\section{EXPERIMENTATION:}

To test our theory, we made an experiment in which 2 profiles were used. It is based on a macro algorithm that includes the following steps:

Manual description experimentation: Manual testing is performed based on the SWEBOK 2004 guide (Spanish Version), using knowledge Quality subtopic. To obtain the result 1 (R1), the following comparisons were performed using a matrix intersection:

$$
\begin{aligned}
\mathrm{C} 1= & \mathrm{KQST} \text { vs PP } \\
\mathrm{C} 2= & (\mathrm{KQST} \text { vs } \mathrm{OP}) \\
\mathrm{C} 3= & (\mathrm{C} 1+\mathrm{C} 2 / 2) \\
\mathrm{R} 1= & \mathrm{C} 3 \\
\mathrm{C} 1= & \sum \text { comparations/nro. Total of comparations } \\
\mathrm{C} 2= & \text { Professional profile } \\
& \text { Occupparations/nro. Total of comparations } \\
\mathrm{C} 3= & \left(\sum \mathrm{C} 1+\sum \mathrm{C} 2\right) / \text { nro total of KQST }
\end{aligned}
$$

Where,

$$
\begin{aligned}
& \mathrm{R} 1=\text { evaluation between professional and occupational } \\
& \text { profiles } \\
& \mathrm{C} 1=\text { Quality Profiles (Skills) } \\
& \mathrm{C} 2=\text { Quality Subtopic and Occupational profiles } \\
& \mathrm{C} 3=\text { Results de C1 and C2 } \\
& \mathrm{KQST}=\text { Knowledge Quality Subtopic } \\
& \mathrm{PP}=\text { Professional Profile } \\
& \mathrm{OP}=\text { Occupational Profile }
\end{aligned}
$$

\begin{tabular}{|c|c|c|c|c|}
\hline \multicolumn{5}{|c|}{$\begin{array}{l}\text { ALINEACION DE CONOCIMIENTO (OFERTA LABORAL VS } \\
\text { SKILL DE CARRERA) }\end{array}$} \\
\hline ofkilab & $\begin{array}{c}\text { Carrera de } \\
\text { ingeniería en } \\
\text { sistemas } \\
\text { computacional } \\
\text { es e } \\
\text { informáticos }\end{array}$ & $\begin{array}{c}\text { Ingeniería } \\
\text { informática } \\
\text { y ciencias de } \\
\text { la } \\
\text { computación }\end{array}$ & $\begin{array}{l}\text { Carrera de } \\
\text { informática } \\
\text { educativa }\end{array}$ & $\begin{array}{l}\text { Ingeniería } \\
\text { electrónica y } \\
\text { computación }\end{array}$ \\
\hline 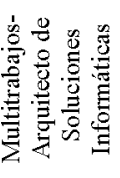 & $42 \%$ & $49 \%$ & $32 \%$ & $28 \%$ \\
\hline 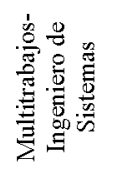 & $35 \%$ & $43 \%$ & $26 \%$ & $21 \%$ \\
\hline 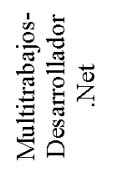 & $28 \%$ & $36 \%$ & $19 \%$ & $14 \%$ \\
\hline 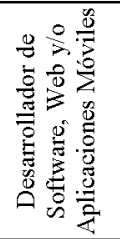 & $32 \%$ & $40 \%$ & $23 \%$ & $18 \%$ \\
\hline
\end{tabular}

In both crosses ( $\mathrm{C} 1$ and $\mathrm{C} 2$ ), in order to obtain numerical data, if there is any similarity it is assigned the value of one, otherwise, the field being analyzed is left in blank. Upon completion of the comparison result $\mathrm{C} 1$ and $\mathrm{C} 2$ in percentages for each subtopic, versus the professional profiles and occupational, respectively bids are obtained. Once the percentages obtained, we proceed to $\mathrm{C} 3$, which consisted on comparing the total percentages of the $\mathrm{C} 1$ and $\mathrm{C} 2$.

TABLE IV. EXPERIMENTATION AND APPLICATION OF FORMULA (SPANISH DATA)

\section{CONCLUSIONS}

The definition of $\mathrm{BOK}$ in the context of software engineering is important to respond the training needs of future professionals, so they in order to they acquire the competencies in the social, business, educational, and industrial.

The professional profiles in Ecuador must be located within a single level of competition, according to the classification established, and validated internationally; the same as described in general terms the knowledge and skills needed to perform within an occupation, the alignment of the profiles compared to job allows industries to identify the basic skills required for the evaluation of professional profiles.

A general structure of $\mathrm{BOK}$ in the software engineering was established. This structure begins with the set of KA, continues with KU, KT and ends with KST according to the research area.

The knowledge description for BOK allows a validated classification of the bounds of the discipline and topical access that will support the discipline, it is subdivided into a set of 
Knowledge Areas allowing readers to find their way quickly to subjects of interest and create its professional profiles.

A BOK can fulfill to stakeholders role in supporting education, certification, professional stature, professional development, and organizational improvement.

\section{ACKNOWLEDGMENT}

The authors express their gratitude to the Technical University of Madrid (UPM) ,in particular to the Doctoral Program of Science and Technology of Computing for Smart Cites, the Department of Information Systems UPM CITSEM, and PhD. Santiago Acosta Aide Vice-Chancellor of the Technical University of Loja for their constantly support.

\section{REFERENCES}

[1] Azuma, M., Coallier, F. and J. Garbajosa, "How to apply the bloom taxonomy to software engineering," in Software Technology and Engineering Practice, 2003. Eleventh Annual International Workshop on, pp. 117-122, Sept 2003.

[2] Bourque, P. Buglione, L, Abran A., \& A. April, "Bloom's taxonomy levels for three software engineer profiles", in Software Technology and Engineering Practice, 2003. Eleventh Annual International Workshop on (pp. 123-129). IEEE. September 2003.

[3] Bourque, P., \& Richard, E., (2014),"Swebok Version 3.0", IEEE, ISBN-10: 0-7695-5166-1

[4] Fazel-Zarandi, M- Fox, M.S. "Semantic Matchmaking for Job Recruitment: An Ontology-Based Hybrid Approach", Proceedings of the 3rd International Workshop on Service Matchmaking and Resource Retrieval in the Semantic Web at the 8th International Semantic Web Conference, ISWC 2010.

[5] Fazel-Zarandi M. "Representing and Reasoning about Skills and Competencies over Time", Doctoral dissertation, University of Toronto, 2013.

[6] J. Han, "Software engineering course design for undergraduates," J. Comput. Sci. Coll., vol. 26, pp. 166-172, Apr. 2011.

[7] Mena, E., Pareja, M. Sicilia, M.A. \& E. García-Bbl., "Deriving competencies from the SWEBOK ontology", in 2nd International Workshop on Ontology, Conceptualization and Epistemology for Software and System Engineering, 2007.

[8] Muller-Riedlhuber, H. "The european dictionary of skills and compe- tencies (disco): an example of usage scenarios for ontologies.," in I- SEMANTICS, pp. 467-479, 2009.

[9] Penzenstadler B., Mendez D., Richardson, D. Callele, and Wnuk, "The requirements engineering body of knowledge (rebok)," in Requirements Engineering Conference (RE), $201321^{\text {st }}$ IEEE International, $p p$. 377-379, July 2013.

[10] UPM (2015), $\quad$ http://mayor2.dia.fi.upm.es/oegupm/index.php/es/methodologies/59-neon-methodology Created under Creative Commons License - OEG.

[11] Rivera-Ibarra, J. Rodriguez-Jacobo, \& M. Serrano-Vargas, "Competency framework for software engineers," in Software Engineering Education and Training (CSEE T), 2010 23rd IEEE Conference on, pp.33-40, March 2010.

[12] Rudzajs P. \&. Kirikova. M "Mediated competency comparison between job descriptions and university courses," Scientific Journal of Riga Technical University. Computer Sciences, 44(1):48- 56, 2011.

[13] Stevens, G.W. "A Critical Review of the Science and Practice of Competency Modeling', Human Resource Development Review, 2012

[14] Taguchi K, Nishihara H, Aoki T., Kumeno T., Hayamizu, K., Shinozaki K., "Building a body of knowledge on model checking for software development," in Computer Software and Applications Conference (COMPSAC), 2013 IEEE 37th Annual, pp. 784-789, July 2013.
[15] Waterson, A., Preece, A, (1999) Verifying ontological commitment in knowledge-based systems, Knowledge-Based Systems, Volume 12 , Issues 1-2, April 1999.

[16] Vera, C., "Mamual de Levantamiento de Perfiles Profesionales", avaible in http:/www.secretariacapacitacion.gob.ec/wpcontent/uploads/2013/07/Manual-de-Levantamiento-de-Perfiles.pdf, Quito-Evcuador, 2011.

[17] SETEC, "Competencias Laborales", avaible in http://www.secretariacapacitacion.gob.ec/category/competenciaslaborales/, 2015

[18] Corcho, O., M. Fernández-López, A. Gómez-Pérez \& A. López-Cima. (2005). "Building Legal Ontologies with METHONTOLOGY and WebODE" en R. Bejamins, R. Casanovas, P. Gangemi, \& P. Selic, Law and the Semantic Web. Springer Verlag.

[19] Sure, Y.; Staab, S.; Rudi, S.; "On-To-Knowledge Methodology (OTKM)", Chapter 6, avaible in http://dx.doi.org/10.1007/978-3-54024750-0 6, Springer, 2004.

[20] Vrandecic, D.; Pinto, S.; Tempich, C.; and Sure, Y. "The DILIGENT knowledge processes", VOL. 9 NO. 5 2005, pp. 85-96, Emerald Group Publishing Limited, ISSN 1367-32702005. 